Наступний напрям є більш складним, ніж перші два. У процесі арт-терапії доводиться задіювати як репродуктивний, так і продуктивний види уяви. Аддикту пропонується по-новому підійти і частково привнести своє у вже існуючий витвір мистецтва. Прикладом може слугувати завдання написати продовження відомого літературного твору (продовження повісті О. Пушкіна «Дубровський»). Пропонується і завдання такого типу - написати літературний твір або художнє полотно із загальновідомою (відомою студенту) назвою (І. Тургенєв «Батьки і діти», Рембрандт «Нічна варта»), але зі своїм сюжетом.

Останній напрям передбачає використання творчої діяльності для встановлення більш тісного емоційного контакту між викладачем і студентом. Вона сприяє персоналізації особистості викладача.

Отже, ми можемо говорити про можливість використання арт-терапії для роботи зі студентами, що мають кіберзалежність.

У процесі впровадження розроблених педагогічних технологій виховання у студентської молоді культури користування кіберпростором ми дійшли висновків про те, що: для подолання комп'ютерної залежності немає необхідності позбавляти комп'ютерно залежну особистість звичного соціального оточення; проблема комп'ютерної залежності особистості перебуває в тісному взаємозв'язку з проблемою особистісної дезадаптації в соціумі; корекція особистісних якостей комп'ютерно залежної особистості змінює ії ставлення до віртуального і реального простору на користь останнього; проблема комп'ютерної залежності особистості має соціальне коріння і відповідно піддається розв'язанню тільки в контексті зміни стосунків комп'ютерної залежної особистості з навколишнім середовищем.

Специфіка змісту розроблених педагогічних технологій зумовлює й особливі вимоги до викладачів, які беруть участь у роботі, спрямовані на виховання у студентської молоді культури користування кіберпростором. Викладачі мають постійно враховувати особливості i спрямованість розвитку духовно-моральної сфери суб'єкта комп'ютерної діяльності (студентська молодь), знати внутрішні психолого-педагогічні механізми, які зможуть забезпечити виховання культури користування кіберпростором, володіти методиками й засобами, які активізують розвиток у студентської молоді культури користування кіберпростором.

\title{
Література
}

1. Ахрямкина Т. А. Психологические аспекты изучения проблемы поведенческой аддикции / Т. А. Ахрямкина, Н. А. Добровидова, Т. П. Жарикова // Психология в вузе : научно-методический журнал. - 2008. - № 2. - С. 80-85. 2. Бех І. Д. Особистісно-орієнтований виховний процес сходження до людяності / І. Д. Бех // Розвиток педагогічної і психологічної науки в Україні 19922002. - 2002. - № 1. - С. 69-83. 3. Зубарев Е. Ю. Приключенческие компьютерные игры в работе психолога [Электронный ресурс] / Е. Ю. Зубарев. - Режим доступа к журналу: http://www.medicinform.net. 4. Кузнецов О. Н. Методические подходы к изучению чувства времени у человека / О. Н. Кузнецов, А. И. Алехин, Т. В. Самохина, Н. И. Моисеева. - М. : Логос, 2001. - 140 с. 5. Леонтьев А. А. Педагогическое общение / А. А. Леонтьев. - М. : Начальник, 1996. - 250 с. 6. Мясникова И. Л. Психология отношений [Электронный ресурс] / И. Л. Мясникова. - Режим доступа у журналу : http://www.koob.ru/myasischev-v1. 7. Психотерапевтическая энциклопедия / под. ред. Б. Д. Карвасарского. - СПб. : Питер, 2000. - 1024 с. 8. Шапкин С. А. Компьютерная игра: новая область психологических исследований / С. А. Шапкин // Психологический журнал. - 1999. - № 1. С. 86-102. 9. Шевченко Г. П. Формування духовної культури учнівської молоді засобами мистецтва / Г. П. Шевченко. - Луганськ, 2008. - 256 с.

УДК 374 (71)

Оксана Юр'єва

\section{ДІЯЛЬНІСТЬ ЖІНОЧИХ ЦЕНТРІВ У ВИЩИХ НАВЧАЛЬНИХ ЗАКЛАДАХ КАНАДИ}

Юр'єва О. Ю. Діяльність жіночих центрів у вищих навчальних закладах Канади.

У статті досліджується діяльність жіночих центрів в університетах Канади та їх роль у реалізації гендерної освіти. Було проаналізовано мету, завдання та основні напрямки їх діяльності. У результаті дослідження було виявлено, що гендерні ініціативи реалізуються переважно $з$ жіночої точки зору, а чоловічі інтереси представлені досить обмеженою кількістю відповідних центрів.

Ключові слова: жіночий центр, гендерна освіта, соціальна справедливість, напрямки діяльності центрів. 
Юрьева О. Ю. Деятельность женских центров в высших учебных заведениях Канады.

В статье изучается деятельность женских центров в университетах Канады и их роль в реализации гендерного образования. Были проанализированы цель, задания и основные направления их деятельности. В результате исследования было установлено, что гендерныне инициативы главным образом реализуются с женской точки зрения, тогда как мужские интересы представлены достаточно ограниченным количеством соответствующих центров.

Ключевые слова: женский центр, гендерное образование, социальная справедливость, направления деятельности центров.

Yurieva O. Yu. The Functioning if Campus Women's Centers in Canadian Universities.

The article examines the functioning of campus Women's Centers in Canadian universities and their role in gender education implementation. The goals, objectives and main areas of work of the centers were analysed. It was found out that gender initiatives are mainly realized from the women's perspective, while men's interests remain underrepresented in the respective centers.

Key words: Women's Center, gender education, social justice, areas of work of the centers

На сучасному етапі розвитку педагогічної науки становлення гендерної освіти є одним із пріоритетних напрямків національної системи освіти. Гендерна освіта - це комплексний процес, який передбачає не лише систематичне офіційне навчання, але й просвіту та самоосвіту. Тому важливим елементом системи поширення та засвоєння гендерних знань $є$ не лише аудиторні заняття, але й діяльність університетських організацій. Одним із прикладів таких організацій у вищій школі Канади слугують жіночі центри, які діють на території університетів. В Україні в останні роки досить інтенсивно відбувається процес організації гендерних центрів і центрів гендерної освіти при вітчизняних університетах. Саме тому закордонний досвід діяльності жіночих центрів може стати корисним для вітчизняної педагогіки.

Питанню дослідження діяльності жіночих центрів на території університетів присвятили свої праці зарубіжні науковці, зокрема, К. Байрн (К. Byrne), Б. Каспер (В. Kasper), Ш. Кункел (C. Kunkel), Ш. Деві (S. Davie) та інші. В Україні частково питання діяльності гендерних центрів вивчали Н. Приходькіна, Л. Смоляр, І. Головашенко, О. Луценко. Проте дослідженню діяльності жіночих центрів у вищих навчальних закладах Канади не було приділено уваги у вітчизняних педагогічних дослідженнях.

Метою статті є проаналізувати діяльність університетських жіночих центрів у Канаді, розкрити їх мету й напрямки діяльності.

Досліджені матеріали надають змогу констатувати, що основним засобом реалізації гендерної освіти у вищих навчальних закладах Канади є дисципліна та спеціальність «Жіночі та гендерні дослідження». Жіночі та гендерні дослідження стали прикладом великого академічного успіху, адже на початку XXI століття програми 3 жіночих та гендерних досліджень спостерігаємо в каталогах майже кожного університету Північної Америки. Вивчення гендеру взагалі і жіночого досвіду зокрема стало офіційним предметом академічного наукового дослідження, викладання і навчання. Для нових поколінь студентів у Канаді важко уявити, яким раніше був університет лише три десятиліття тому, коли про університетські курси жіночих, гендерних і феміністичних досліджень майже ніхто не чув. Емпіричне дослідження життя жінок, критичне вивчення жіночих соціальних умов і теоретичне дослідження статі, гендеру і сексуальності, такі невід'ємні частини творення знання у XXI столітті, є насправді новими явищами, які тісно увійшли в культуру сучасних канадських університетів та стали вагомою частиною не лише офіційних дисциплін і курсів, але й позааудиторного життя університету.

Важливу роль у реалізації гендерної освіти у вищих навчальних закладах Канади відіграють жіночі центри, що діють на території фактично усіх університетів у співпраці із кафедрами жіночих досліджень гуманітарних факультетів. Згідно з даними канадського довідника університетів (Canada's Higher Education and Career Guide), основними напрямками діяльності таких центрів $є$ консультування чоловіків і жінок із питань гендерної рівності, організація та координація подій та кампаній, пов'язаних з проблемами гендерної рівності та соціальної справедливості [11]. Аналіз літератури 3 окресленого питання дозволяє 
стверджувати, що жіночі центри виникли на території коледжів та університетів Канади на початку 70-х років XX століття, коли набув активності жіночий рух. Нині вони отримують фінансування 3 різних джерел: одні фінансуються адміністрацією університетів та отримують кошти зі студентської плати за навчання, інші отримують фінансування із зовнішніх джерел, таких, як гранти або благодійні пожертвування. Деякі центри організовані й керуються студентами, інші мають офіційно чинне керівництво й адміністративну підтримку [3]. Незважаючи на такі відмінності, жіночі центри об'єднані однією ідеєю задовольнити потреби жінок, які навчаються в університеті. Американська дослідниця Ш. Кункел (C. Kunkel) виокремлює п'ять таких основних потреб: безпека, освіта, підтримка та захист, справедливість і спільність [5]. Необхідно зазначити, що можливість поєднувати теорію з практикою робить жіночі центри важливим компонентом реалізації феміністської педагогіки. Зокрема, так стверджує К. Байрн (К. Bуrne), яка вбачає в активістських програмах, що підтримуються такими центрами, основу для організації стажування, семінарів, конференцій для програм жіночих досліджень та інших університетських програм [1].

Дослідження офіційних веб-сторінок жіночих центрів найбільших університетів Канади [2; 7; 8; 9] надало змогу визначити основні цілі їх діяльності, які головним чином спрямовані на покращення становища жінок. Так, основними завданням центрів $\epsilon$ забезпечення сприятливої атмосфери та підтримки під час навчання, налагодження контактів та організація заходів із специфічних жіночих питань в університеті та за його межами. Працівники центрів ставлять собі за мету боротися з усіма формами утисків та виступати за соціальну справедливість, працювати заради повного залучення жінок до життя суспільства та забезпечувати жінкам можливість доступу до ресурсів про жінок та таких, що позитивно зображують жінок. Жіночі центри є своєрідним осередком для розміщення й поширення інформації з гендерних питань, зокрема, у них нерідко укладаються спеціалізовані бібліотеки, збираються архівні та довідкові матеріали на гендерну тематику, до яких мають доступ усі студенти університету та відвідувачі центру. У жіночих центрах також пропонують різноманітні безкоштовні продукти для студентів і викладачів, включаючи засоби гігієни, контрацептиви та підгузки для дітей. У таких центрах жінки мають змогу отримати інформацію та конфіденційні консультації з різних питань, пов'язаних із жіночим та репродуктивним здоров'ям, насильством, доглядом за дітьми. Персонал центрів може направляти жінок до лікарів, допомагає знайти доглядальників для дітей, надає допомогу в розв'язанні житлових питань.

Аспектом роботи жіночих центрів $є$ їх співпраця з громадськими організаціями задля зниження рівня жіночої бідності. Разом вони надають підтримку дослідженням проблеми бідності у громаді, поширюють інформацію і розробляють стратегії для підвищення економічної захищеності жінок. Одним із шляхів боротьби із жіночою бідністю серед студентів $\epsilon$ надання інформації для жінок про жіночі стипендії та гранти і допомога студентам у процесі отримання позики на навчання. Крім вищезазначеного, їх діяльність, спрямована на покращення економічної стабільності жінок, передбачає допомогу одиноким матерям у отриманні доступного житла на території університету, якщо ті не можуть собі дозволити жити за межами університету.

Задля стабільної діяльності протягом навчального року жіночі центри проводять регулярні щотижневі зустрічі. Одним із важливих напрямків роботи центрів $є$ організація та проведення конференцій, присвячених проблемам жіночого здоров'я, бідності, насильства та нерівності на робочому місці. Крім того, у співпраці із університетськими службами з питань рівності та прав людини, жіночі центри регулярно організовують безкоштовні тренінги та семінари, відкриті для студентів та оточуючої громади (теми семінарів, наприклад, такі: консенсус у прийнятті рішень, гендерні «ізми» i захист прав, анти-расизм, аблеїзм і протистояння дискримінації). Намагаючись привернути увагу до проблем жінок, персонал центрів організовує різноманітні заходи, присвячені зниклим безвісти та вбитим корінним жінкам, жінкам, постраждалим від насильства, маргіналізованим жінкам і квір-спільноті, святкуванню міжнародного жіночого дня й інші.

Варто зазначити, що вагомий внесок у роботу центрів здійснюють волонтери, які працюють у кожному з напрямків діяльності жіночих центрів. Вони проходять навчання 3 питань допомоги під час сімейних конфліктів і володіють інформацією про проблеми, з якими стикається велика кількість жінок, які опиняються у таких складних ситуаціях. Волонтери і психологи надають 
психологічну підтримку та спрямовують постраждалих від сімейного насильства до різних університетських і громадських служб. На допомогу жінкам, які стали жертвами сексуальних злочинів або хочуть повідомити про фізичне чи емоційне знущання, діє гаряча лінія.

Завдяки роботі університетських жіночих центрів доступною для студентства стає низка інших ресурсів, таких, як приміщення для поліції, юридичної допомоги і служби супроводу та охорони (WalkSafe). Оскільки низка питань, якими опікуються жіночі центри, подібні до питань, якими займаються ЛГБТ-центри, іноді займають одне приміщення або об'єднані в один центр з персоналом, який надає допомогу в обох випадках. Центри, що представляють інтереси інших груп меншин, такі, наприклад, як центри корінного населення, також часто мають тісні зв'язки з жіночими центрами.

Варто зазначити, що всі університетські жіночі центри Канади працюють на засадах фемінізму та підтримують ідеї боротьби 3 расизмом, сексуальної просвіти, підтримки репродуктивних прав жінок і прав ЛГБТ-меншин. Вони підтримують боротьбу за політичну, економічну i соціальну справедливість. Модель діяльності жіночих центрів у вищих навчальних закладах Канади, зображена на малюнку 1, ілюструє охоплення такими центрами широкого спектру проблем, для розв'язання яких центри активно працюють у різних напрямках. Водночас центри недостатньою мірою відображають і залучають до своєї роботи чоловіків і чоловічий досвід.

В умовах, коли в Канаді досить активно працюють жіночі центри, цікавим явищем $є$ поява чоловічих центрів. Успішним прикладом функціонування такого центру є Чоловічий ресурсний центр у Вінніпезі, який спочатку був відкритий при Університеті Манітоби, а згодом приєднався до некомерційної організації та відокремився від університету. Завданнями цього центру є забезпечення підтримки чоловікам, які перебувають у стресових ситуаціях, у зв'язку з ситуативними чи віковими обставинами, задля зменшення ймовірності заподіяння шкоди собі чи іншим та запобігання таким ситуаціям, а також надання чоловікам можливості займатися волонтерською діяльністю в центрі. Центр працює на засадах відмови від обмежень, накладених гендерними ролями, та підтримує роль чоловіків у творенні суспільства, заснованого на принципах справедливості i паритету. Працівники центру поважають різноманітність чоловіків, включаючи відмінності у віці, класі, культурі, сексуальній орієнтації чи релігії. Чоловічий центр пропонує безкоштовні психологічні консультації у зручній і звичній чоловікам формі. Крім того, працівники центру проводять тренінги та семінари на різноманітні теми, наприклад, «Як зростати без батька», «Чоловіки і відносини», «Чоловіки і почуття власної гідності», «Чоловіки і комунікація», відбуваються зустрічі групи для чоловіків, що зазнали сексуального насильства. При центрі діє притулок для чоловіків та їх дітей, які зазнають насильства та жорстокого поводження у родині [6]. Згідно з інформацією, поданою на сайті центру, він $є$ одним із чотирьох подібних центрів у Канаді, що, безперечно, становить незначну кількість таких організацій на такій великій території.

Нещодавні спроби організувати чоловічий центр в Університеті Саймона Фрейзера спричинили значні дебати та викликали велику кількість критики з боку жіночого центру цього ж університету. Реакцією жіночого центру університету на відкриття та фінансування цієї ініціативи була стурбованість тим, що чоловічий центр не захищатиме права маргіналізованих чоловіків, і була висловлена думка про відсутність потреби його відкривати, оскільки «чоловічий центр існує усюди» [10]. Проте саме обговорення цієї події у пресі серед прихильників чи опонентів цього питання привернуло увагу громадськості до чоловічих питань у Канаді. Так, засоби масової інформації заговорили про наявність чоловічих проблем, невиголошеність їх у суспільстві та потребу їх розв'язання. Зокрема, згідно з Канадським інститутом інформації про здоров'я, серед проблем, яких зазнають канадські чоловіки високий рівень самогубств, який у чотири рази вищий, ніж серед жінок, вищий, ніж у жінок, рівень зловживання алкоголем, високий кількісний показник безпритульних (70\% чоловіки) та інші. Водночас суспільство соціалізує чоловіків так, що вони не виносять на загал свої проблеми, і саме тому необхідно порушувати цю проблему [4]. Очевидним стає той факт, що чоловічі питання потребують не меншої уваги, ніж жіночі, і повинні доповнювати одне одного в сучасних гендерних дослідженнях. 


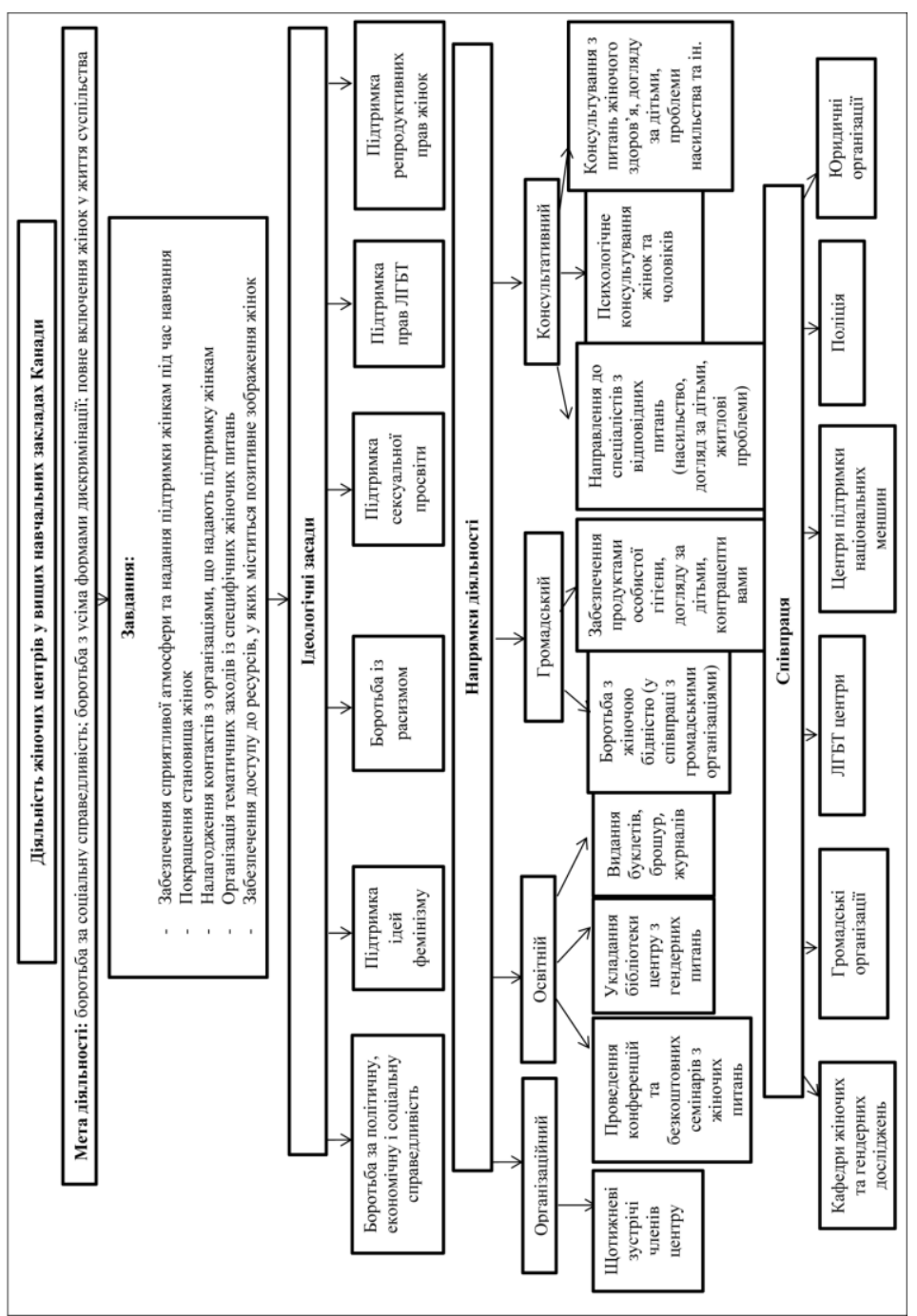

Рис. 1. Діяльність Жіночих центрів у вищих навчальних закладах Канади

Отже, діяльність жіночих центрів на території канадських вищих навчальних закладів об'єднується спільною метою участі жінок у житті суспільства взагалі та діяльності університету зокрема. Особлива підтримка надається жінкам з особливими потребами та жінкам, які потрапили у складні життєві ситуації, щоб надати їм змогу упевнено почуватися у стінах навчального закладу. Центри відіграють важливу роль у процесі реалізації гендерної освіти, оскільки вони поєднують практику із теорією, оскільки діяльність центрів не обмежується лише освітньою або просвітньою, але включає і громадську та консультативну. Проте аналіз діяльності чоловічих центрів на території Канади засвідчив, що чоловічі проблеми продовжують замовчуватись серед громадськості. Аналіз досвіду діяльності центрів такого зразка становить інтерес для української педагогіки і тому вимагає подальшого вивчення. 


\section{Література}

1. Byrne K. The Role of Campus-based Women's Centers/ Kelly Zaytoun Byrne // Feminist Teacher. 2000. - Vol. 13, № 1. - P. 48-60. 2. Center for Women + Trans People [Електронний ресурс]. - Режим доступу: http://womenscentre.sa.utoronto.ca/. 3. Kasper В. Campus-based Women's Centers: Administration, Structure, and Resources / Barbara Kasper// NASPA Journal. - 2004. - Vol. 41, № 3. - P. 487-499. 4. Kielburger C. Should Universities be Opening Men's Centers?/ Mark and Craig Kielburger// The Globe and Mail. - Published on Monday, Jul. 23, 2012 [Електронний ресурс]. - Режим доступу: http://www.theglobeandmail.com/life/giving/should-universities-be-opening-mens-centres/article4436249/.

5. Kunkel C. A. Women's Needs on Campus: How Universities Meet Them / Charlotte A. Kunkel // Initiatives. - 1994. - Vol. 56, № 2. - P. 15-28. 6. Men’s Resource Center [Електронний ресурс]. - Режим доступу: http://www.mens-resource-centre.ca/. 7. Simon Fraser Student Society [Електронний pecypc]. Режим доступу: http://sfss.ca/womens-centre/about-the-collective. 9. University of Alberta Women's Center Collective [Електронний ресурс]. - Режим доступу: http://uawcc.wordpress.com/about/. 10. UVSS Women's Center [Електронний pecypc]. - Режим доступу: http://www.uvss.uvic.ca/wcentre/ collective.asp. 11. Wakeman J. Why A Men's Center at Canada's Simon Fraser University should not be Controversial / Jessica Wakeman // The Frisky. - Published on June 11, 2012 [Електронний ресурс]. Режим доступу: http://www.thefrisky.com/2012-06-11/why-a-mens-center-at-canadas-simon-fraseruniversity-should-not-be-controversial/. 12. Women's Centers in Canadian Universities [Електронний pecypc]. - Режим доступу: http://www.canadian-universities.net/Campus/Womens-Centres.html.

Олена Яковенко

\section{ДОСЛІДЖЕННЯ ПЕДАГОГІЧНИХ УМОВ ФОРМУВАННЯ ПРОФЕСІЙНИХ КОМПЕТЕНЦЙ МАЙБУТНІХ ЕКОНОМІСТІВ}

Яковенко О. І. Дослідження педагогічних умов формування професійних компетенцій майбутніх економістів.

У статті обгрунтовується необхідність побудови навчального процесу на засадах визначених педагогічних умов для ефективного формування професійної компетентності майбутніх економістів. На основі дослідження робіт науковців сформульовано власне визначення поняття «педагогічні умови» та запропоновано їх комплексну систему для економічної освіти.

Ключові слова: економічна освіта, інтерактивні методи навчання, інформатизація навчання, компетентністний підхід, педагогічні умови, практико-орієнтоване навчання, професійна компетентність.

Яковенко Е. И. Исследование педагогических условий формирования профессиональных компетенций будущих экономистов.

В статье обосновывается необходимость построения процесса обучения на основе выявленных педагогических условий для более эффективного формирования профессиональных компетенций будущих экономистов. На основании исследования работ ученых сформулировано свое определение понятия «педагогические условия» и предлагается их комплексная система для экономического образования.

Ключевые слова: экономическое образование, интерактивные методы обучения, информатизация обучения, компетентностный подход, педагогические условия, практикоориентированное обучение, профессиональная компетентность.

Yakovenko O. I. Study of pedagogical conditions of formation of professional competence of future economists.

The article is based upon the need of building a learning process on the basis of certain pedagogical conditions for more effective professional competence of future economists. Based on the research work of scientists gives his own definition of «pedagogical conditions» and offer them a comprehensive system for economic education.

Key words: economic education, interactive teaching methods, informatization of education, competent approach, pedagogical conditions, practically oriented training, professional competence. 